\title{
AKTIVITAS ANTIOKSIDAN KOMBINASI EKSTRAK ETANOL KAYU SECANG (Caesalpinia sappan L.) DAN KELOPAK BUNGA ROSELLA (Hibiscus sabdariffa \\ L.)
}

\author{
Risfah Yulianty, Mufidah Murdifin, Nur Asma \\ Fakultas Farmasi Universitas Hasanuddin, Makassar
}

\begin{abstract}
ABSTRAK
Senyawa radikal bebas merupakan produk samping dari metabolisme normal tubuh yang dapat menyebabkan terjadinya oksidasi seperti kerusakan membran, modifikasi protein, kerusakan DNA, dan kematian sel. Penggunaan antioksidan dapat meredam dan menangkap radikal bebas. Tumbuhan yang memiliki aktivitas antioksidan yaitu kayu secang (Caesalpinia sappan) dan bunga rosella (Hibiscus sabdariffa L). Tujuan dari penelitian ini adalah untuk mengetahui aktivitas antioksidan dari kombinasi ekstrak etanol kayu secang dan kelopak bunga rosella menggunakan metode microplate 1,1-diphenyl-2picrylhydrazine (DPPH). Hasil penelitian menunjukkan bahwa nilai $\mathrm{IC}_{50}$ dari kombinasi ekstrak etanol kayu secang dan bunga rosella dengan perbandingan 1:0, 2:1, 1:1, 1:2, dan $0: 1$ berturut-turut sebesar 11,$46 ; 12,34 ; 16,79 ; 19,93 ;$ dan $680,37 \mu \mathrm{g} / \mathrm{ml}$, sedangkan nilai IC $_{50}$ vitamin $\mathrm{C}$ sebesar $4,77 \mu \mathrm{g} / \mathrm{ml}(\alpha<0,01)$. Hal ini menunjukkan bahwa ekstrak tunggal bunga rosella (0:1) menunjukkan aktivitas antioksidan yang lebih rendah dibandingkan dengan vitamin $\mathrm{C}$. Penelitian ini dapat disimpulkan bahwa kombinasi ekstrak kayu secang dan bunga rosella pada perbandingan $2: 1,1: 1$, dan 1:2 memiliki efek yang sinergi berdasarkan Nilai Indeks Kombinasi $(\mathrm{CI}<1)$.
\end{abstract}

Kata Kunci: antioksidan, indeks kombinasi, kayu secang, rosella

\section{PENDAHULUAN}

Senyawa radikal bebas merupakan produk samping proses metabolisme normal dari tubuh seperti metabolisme sel, fagositosis, metabolisme asam arakidonat, ovulasi, dan fertilisasi. Produksi radikal bebas mengalami peningkatan selama kondisi patologis terutama Reactive Oxygen Spicies (ROS) (1).

Radikal bebas dapat menyerang lipid, protein/enzim, karbohidrat, DNA dalam sel atau jaringan, sehingga dapat menyebabkan oksidasi yang memicu kerusakan membran, modifikasi protein, kerusakan DNA dan kematian sel yang diinduksi oleh fragmentasi DNA dan peroksidasi lipid. Kerusakan oksidatif yang disebabkan oleh produksi ROS tidak hanya terlibat dalam toksisitas xenobiotik, tetapi juga pada proses penuaan dini, beberapa penyakit jantung (aterosklerosis), katarak, disfungsi kognitif, kanker (neoplastik), retinopati diabetik, penyakit inflamasi kronis, disfungsi organ, kerusakan pembuluh vaskuler, penyakit neurodegeneratif $(1,2)$, asma, obstruktif paru-paru kronis, hipertensi, influensa, infark miokard, pneumonia. Olahraga berlebihan, peradangan atau ketika tubuh terpapar polusi lingkungan seperti asap rokok, asap kendaraan, bahan pencemar, toksin, pestisida, radiasi ultra violet juga dapat menghasilkan radikal bebas.(3).

Produksi radikal bebas dalam tubuh terus meningkat karena adanya pengaruh eksternal, sistem pertahanan antioksidan tubuh tidak bekerja efektif sebagai pelindung serangan radikal bebas sehingga terjadi stres oksidatif. Untuk mencegah terjadinya stres oksidatif diperlukan suplemen antioksidan yang dapat meredam dan menangkap radikal 
bebas $(1,3)$. Bila kadar antioksidan seluler dalam tubuh kurang sehingga tidak efektif memerangkap radikal bebas maka diperlukan antioksidan eksogen. Beberapa senyawa alamiah eksogen yang terdapat dalam makanan antara lain tokoferol, $\beta$-karoten, asam askorbat dan senyawa mikronutrien seng ( $\mathrm{Zn}$ ), dan selenium (Se) (4).

Kayu secang (Caesalpinia sappan L.) sebagai minuman herbal digunakan untuk pengobatan darah kotor, antidiabetik, antitumor, antimikroba, antivirus, antikoagulan, antiinflamasi, imunostimulan, dan sitotoksik terhadap sel kanker $(5,6)$. Ekstrak kayu secang mengandung lima senyawa yang terkait flavonoid yang mempunyai aktivitas antioksidan primer dan sekunder adalah 1) brazilin; 2) isomer brazilin; 3) 1',4'dihidrospiro[benzofuran-3(2H),3'-[3H-2] benzopiran]-1',6',6',7'-tetrol; 4) 3-[[4,5 dihidroksi2-(hidroksimetil)fenil]metil]-2-3-dihidro-3,6-benzofurandiol; 5) $(7 \mathrm{R}, 7 \mathrm{~S})-7,8-$ dihidro-3,7,10,11-tetrahidroksi-6H-dibenz[b,d]oksosin-7-metanol(7R-7S-protosapanin B) (7). Brazilin memiliki aktivitas penghambatan lipase dengan nilai inhibitory concentration $\left(\mathrm{IC}_{50}\right)$ sebesar $6 \mu \mathrm{M}$, protosappanin A sebesar $100 \mu \mathrm{M}$. Nilai $\mathrm{IC}_{50}$ aktivitas antioksidan brazilin $8,8 \mu \mathrm{M}$ tidak berbeda nyata dengan protosappanin $\mathrm{A}(9,1 \mu \mathrm{M})$ dan $(+)$ katekin $(10,2 \mu \mathrm{M})$, sedangkan sappanon B 14,5 $\mu \mathrm{M}(8)$. Nilai $\mathrm{IC}_{50}$ ekstrak kayu secang komersial adalah 13,406 $\mu \mathrm{g} / \mathrm{mL}$, ekstrak kayu secang berusia 2 tahun adalah 10,242 $\mu \mathrm{g} / \mathrm{mL}$, dan ekstrak kayu secang berusia 30 tahun adalah 11,656 $\mu \mathrm{g} / \mathrm{mL}(9)$.

Rosella (Hibiscus sabdariffa L.) merupakan herba tahunan dari suku Malvaceae yang dapat hidup dengan kondisi lahan, cuaca, serta suhu apapun, akan tetapi di setiap daerah yang berbeda akan menghasilkan warna yang berbeda pula. Setiap bagian tanaman rosella mempunyai kandungan senyawa kimia yang bermanfaat untuk pengobatan maupun sebagai bahan makanan. Salah satu diantaranya adalah corolla (mahkota) bunga rosella yang memiliki kandungan kimia antara lain antosianin, beta karoten, vitamin $\mathrm{C}$, tiamin, riboflavin, flavonoid dan niasin (10). Nilai $\mathrm{IC}_{50}$ ekstrak etanol $60 \%$ bunga rosella adalah $465,88 \mu \mathrm{g} / \mathrm{mL}$, ekstrak etanol $95 \%$ bunga rosella adalah $1051,72 \mu \mathrm{g} / \mathrm{mL}$, dan ekstrak air bunga rosella adalah $486,52 \mu \mathrm{g} / \mathrm{mL}$ (11).

Salah satu pengujian aktivitas antioksidan adalah pemerangkapan radikal bebas DPPH. Apabila radikal bebas DPPH direaksikan dengan antioksidan atau sampel yang mengandung antioksidan, akan terjadi reaksi penangkapan hidrogen $(\mathrm{H})$ dari antioksidan oleh radikal bebas DPPH dan menyebabkan perubahan warna DPPH dari ungu menjadi kuning (12).

Kayu Secang dan Bunga Rosella telah sering digunakan masyarakat sebagai minuman herbal yang dikombinasikan dengan kepercayaan akan memperoleh hasil yang lebih baik. Berdasarkan uraian di atas maka masalah yang timbul adalah apakah kombinasi ekstrak Kayu Secang dan Bunga Rosella dapat memberikan aktivitas antioksidan yang lebih baik. Tujuan penelitian ini adalah untuk mengetahui aktivitas antioksidan dari kombinasi ekstrak Kayu Secang dan Bunga Rosella dengan menggunakan metode DPPH (1,1-difenil-pikrilhidrazin).

\section{METODE PENELITIAN}

\section{Alat dan Bahan}

Alat-alat yang digunakan dalam penelitian ini adalah freeze dryer (Heto Powerdry LL1500), fruit dryer (Excalibur 3900B), labu tentukur, mikropipet multichannel (Eppendorf), oven, peralatan gelas, seperangkat alat KLT, microplate reader (BioTek Elx808), sonikator (Elmasonic E30H), dan timbangan analitik (Denver SI-234). Bahanbahan yang digunakan adalah aluminium foil, air suling, asam sitrat, Bunga Rosella (Hibiscus sabdariffa L.), DPPH (1,1-difenil-2-pikrilhidrazil), etanol 70\%, kain saring, 
Kayu Secang (Caesalpinia sappan L.), lempeng KLT, metanol p.a, dan microplate 96well.

\section{Proses Ekstraksi Kayu Secang}

Ekstraksi dilakukan menggunakan metode maserasi yang dibantu proses sonikasi. Kayu secang sebanyak 100 g diekstraksi dengan etanol $70 \%$ sebanyak $500 \mathrm{ml}$ pada suhu $30^{\circ} \mathrm{C}$ selama 3 jam. Cairan penyari kemudian dipisahkan dengan penyaringan dan diekstraksi ulang dengan menggunakan penyari baru yang sama dengan sebelumnya. Pekerjaan ini dilakukan sebanyak 3 kali dengan kondisi yang sama. Cairan penyari kemudian diliofilisasi menggunakan freeze dryer sehingga diperoleh ekstrak dalam bentuk serbuk.

\section{Proses Ekstraksi Bunga Rosella}

Ekstraksi dilakukan dengan menggunakan metode maserasi yang dibantu proses sonikasi. Sebanyak $100 \mathrm{~g}$ bunga rosella diekstraksi dengan etanol $70 \%$ yang telah diasamkan dengan asam sitrat $3 \%$ sebanyak $500 \mathrm{ml}$ pada suhu $30^{\circ} \mathrm{C}$ selama 30 jam. Cairan penyari kemudian dipisahkan dengan penyaringan dan diekstraksi ulang dengan menggunakan penyari baru yang sama dengan sebelumnya. Pekerjaan ini dilakukan sebanyak 3 kali dengan kondisi yang sama. Cairan penyari kemudian diliofilisasi menggunakan freeze dryer sehingga diperoleh ekstrak dalam bentuk serbuk.

\section{Kromatografi Lapis Tipis (KLT)}

Lempeng KLT diaktifkan dalam oven suhu $105-110^{\circ} \mathrm{C}$ selama 1 jam. Ukuran lempeng yang digunakan adalah $5 \times 7 \mathrm{~cm}$, ditandai batas bawah pada jarak $1 \mathrm{~cm}$ dan batas atas pada jarak $0,5 \mathrm{~cm}$. Sampel ekstrak kombinasi dilarutkan dengan metanol p.a kemudian ditotolkan pada batas bawah dengan menggunakan pipa kapiler. Lempeng KLT dimasukkan ke dalam chamber yang telah dijenuhkan dengan pengelusi etil asetat-heksan (3:2). Lempeng dielusi sampai batas atas. Noda yang muncul diamati pada UV $254 \mathrm{~nm} \&$ $366 \mathrm{~nm}$ serta divisualisasikan dengan $\mathrm{H}_{2} \mathrm{SO}_{4} 10 \%$. Noda yang muncul dicatat dan dihitung nilai Rf-nya.

\section{Uji KLT - autografi}

Hasil KLT di atas disemprot dengan larutan DPPH $240 \mu \mathrm{M}$. Noda yang memiliki aktivitas anti radikal bebas tampak sebagai noda berwarna kuning keputihan dengan latar belakang ungu.

\section{Uji Aktivitas Antioksidan dengan Metode DPPH Menggunakan Microplate Reader}

Larutan DPPH $(240 \mu \mathrm{M}) 75 \mu \mathrm{L}$ dimasukkan ke dalam lubang microplate 96-well, lalu ditambahkan $125 \mu \mathrm{L}$ metanol p.a. Campuran ekstrak kayu secang dan ekstrak bunga rosella ditimbang sebanyak $5 \mathrm{mg}$ yang sebelumnya telah dibuat perbandingan sebesar 1:0; $2: 1 ; 1: 1 ; 1: 2$ dan 0:1. Masing-masing campuran diencerkan dengan pelarut metanol p.a. sehingga diperoleh stok larutan uji $100 \mathrm{ppm}$. Larutan stok dipipet sebanyak $10 \mu \mathrm{L}, 20 \mu \mathrm{L}$, $40 \mu \mathrm{L}$, dan $80 \mu \mathrm{L}$ dan dimasukkan ke dalam wellplate lalu ditambahkan $75 \mu \mathrm{L}$ larutan DPPH $(240 \mu \mathrm{M})$ di setiap well yang telah berisi ekstrak kombinasi, kemudian volume campuran dicukupkan sampai $200 \mu \mathrm{L}$ dengan penambahan metanol p.a. hingga diperoleh seri konsentrasi larutan uji 5, 10, 20, dan $40 \mathrm{ppm}$. Selanjutnya microplate 96-well diinkubasi selama 30 menit pada suhu $37^{\circ} \mathrm{C}$ lalu diukur absorbansinya menggunakan Microplate Reader pada panjang gelombang $515 \mathrm{~nm}$. Besarnya persentase pengikatan radikal bebas DPPH dapat dihitung menggunakan rumus:

$$
\text { absorbansi kontrol negatif-absorbansi sampel }
$$

$\%$ aktivitas antioksidan $=\frac{\text { absorbansi kontrol negatif }}{\text { a }}$ 


\section{Analisis Data}

Nilai IC50 selanjutnya dianalisis perbedaannya secara statistik menggunakan metode ANOVA dengan software SPSS versi 16.

\section{HASIL DAN PEMBAHASAN}

Metode ekstraksi yang digunakan pada kayu secang (Caesalpinia sappan L.) dan bunga rosella (Hibiscus sabdariffa L.) adalah metode sonikasi. Metode ini dipilih untuk meminimalisir pengaruh suhu tinggi pada proses ekstraksi dibandingkan dengan metode lain dan metode ini lebih cepat dibandingkan dengan metode maserasi. Hal ini diperlukan untuk menghindari kontak yang terlalu lama antara senyawa yang terkandung dengan penyari yang bisa mengakibatkan terbentuknya senyawa lain (artificial compounds).

Pelarut yang digunakan untuk menyari adalah etanol 70\%. Pelarut ini dipilih karena memiliki kepolaran yang tinggi sehingga mudah diserap oleh membran sel. Selain itu, pelarut yang bersifat polar akan mudah melarutkan senyawa polifenol yang bersifat polar, di antaranya tanin dan flavonoid. Etanol juga mudah menguap sehingga mudah dibebaskan dari ekstrak. Ekstraksi kadar antosianin pada bunga rosella juga diketahui bahwa penggunaan etanol sebagai penyari dapat menghasilkan kadar antosianin yang lebih besar dibandingkan dengan metanol (13). Bunga rosella diekstraksi menggunakan etanol $70 \%$ dengan penambahan asam sitrat 3\% agar terbentuk suasana asam. Dalam suasana asam, struktur dominan antosianin dalam bunga rosella berada dalam bentuk inti kation flavium (aglikon antosianidin) terprotonisasi dan kekurangan elektron. Peningkatan nilai $\mathrm{pH}$ menyebabkan kation flavilium (antosianidin) menjadi tidak stabil dan mudah mengalami transformasi struktural menjadi senyawa tidak berwarna (kalkon). Apabila nilai $\mathrm{pH}$ semakin rendah, maka warna konsentrat makin merah dan stabil atau jika $\mathrm{pH}$ semakin mendekati angka 1 (satu) maka warna semakin stabil. Hal ini disebabkan bentuk pigmen antosianin pada kondisi asam adalah kation flavium dan inti kation flavium, dimana jumlah elektron pada inti kation flavium sedikit sehingga sangat reaktif (14). Asam sitrat memiliki sedikit sifat antioksidan sehingga memberi efek sinergi terhadap antioksidan yang lain, yaitu dapat membantu efek antioksidan primer (15). Hasil rendamen ekstrak dari bunga rosella menunjukkan jumlah ekstrak yang diperoleh melebihi 50\%. Derajat keasaman yang rendah pada pelarut menyebabkan penarikan antosianin yang lebih banyak dibandingkan tanpa penambahan asam. Ekstrak etanol 70\% bunga rosella stabil (berwarna merah muda) pada $\mathrm{pH} 25$, sedangkan ekstrak kayu secang berwarna orange pada $\mathrm{pH} 8,6-9,4$, berwarna merah-orange pada $\mathrm{pH} 7,0-8,6$, dan berwarna kuning pada $\mathrm{pH} 3,86,2 \quad(16,17,18)$. Kombinasi ekstrak kayu secang dan bunga rosella menghasilkan warna kuning. Hal ini disebabkan pengaruh $\mathrm{pH}$ yang rendah dari bunga rosella sehingga terjadi pergeseran $\mathrm{pH}$ dan menyebabkan warna kombinasi ekstrak menjadi kuning ( $\mathrm{pH} \mathrm{3,8-6,2).} \mathrm{Hasil} \mathrm{ekstraksi}$ dari simplisia kayu secang dan bunga rosella masing-masing berupa ekstrak kering dengan rendamen 47 dan $56 \%$.

Ekstrak Kayu Secang dan Bunga Rosella kemudian dicampur dengan perbandingan 1:0, 1:1, dan 0:1. Hasil pencampuran ekstrak kemudian dianalisis secara kualitatif menggunakan KLT dengan fase diam berupa silika gel GF 254 dan fase gerak berupa campuran etil asetat dan n-hexan (3:2). Pengamatan dilakukan dengan sinar UV 254, UV 366 dan $\mathrm{H}_{2} \mathrm{SO}_{4} 10 \%$ (Gambar 1). Berdasarkan hasil KLT menunjukkan adanya kesamaan spot pada masing-masing ekstraknya sehingga campuran ekstrak yang digunakan adalah homogen.

Uji aktifitas antioksidan secara KLT-autografi dengan pereaksi DPPH terbentuk noda putih kekuningan dengan latar belakang ungu (Gambar 1 (d)). Hal ini menunjukkan bahwa spot pada ekstrak tunggal kayu secang, ekstrak tunggal bunga rosella, dan ekstrak 
kombinasi kayu secang dan bunga rosella seluruhnya memiliki aktivitas antioksidan. Pengukuran aktivitas antioksidan dilakukan menggunakan metode DPPH dengan microplate. Metode ini adalah salah satu uji untuk mengetahui seberapa besar aktivitas kombinasi ekstrak kayu secang dan ekstrak kelopak bunga rosella sebagai antioksidan. Metode pengujian menggunakan microplate lebih cepat, menghemat sampel, dan lebih ramah lingkungan dibandingkan metode lainnya (19).
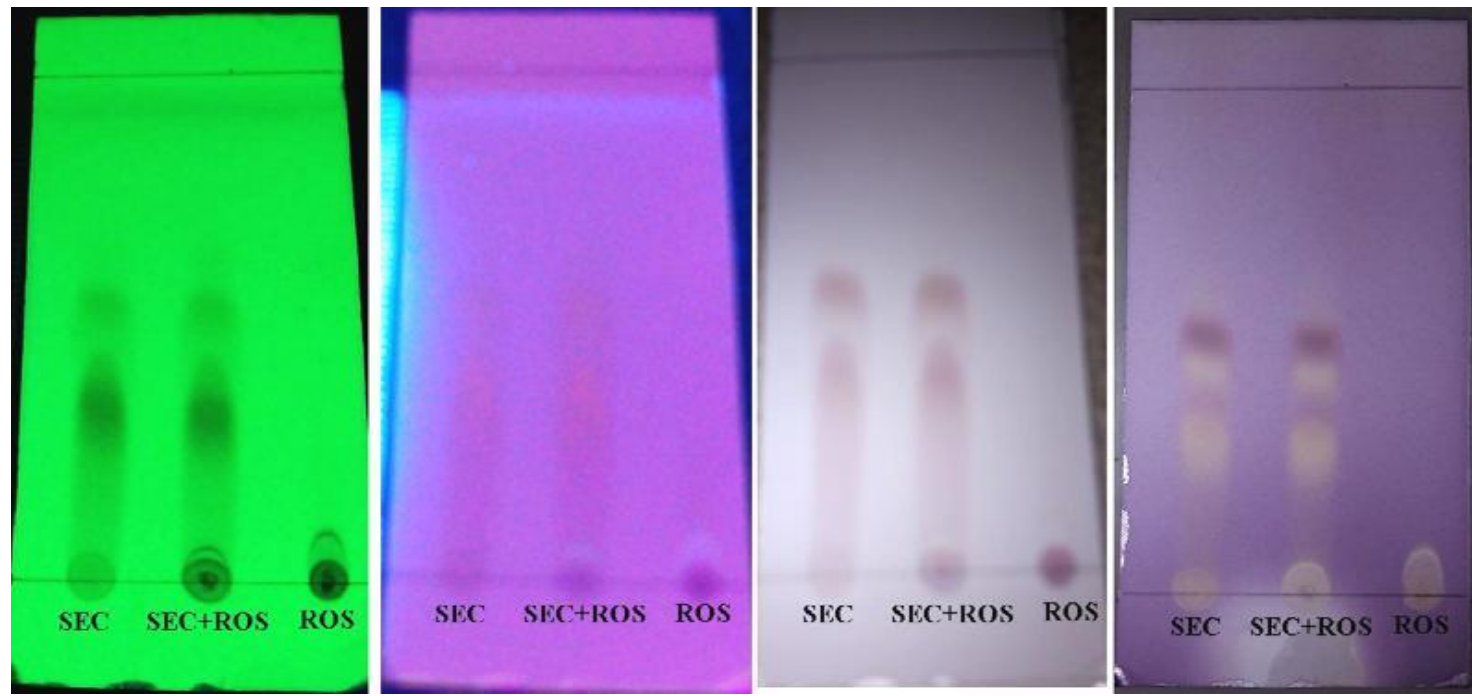

Gambar 1. Profil KLT Ekstrak Tunggal Kayu Secang (SEC), Ekstrak Kombinasi Kayu Secang dan Bunga Rosella (SEC+ROS), dan Ekstrak Tunggal Bunga Rosella (ROS). (a) UV 254 nm; (b) UV 366 nm; (c) H2SO4 10\%; (d) Hasil Penyemprotan dengan DPPH. Fase Gerak: Etil Asetat : Hexan (3:2)

Ekstrak etanol dari kayu secang dan bunga rosella yang direaksikan dengan larutan DPPH langsung mengubah warna ungu dari larutan DPPH menjadi kuning pucat. Perubahan intensitas warna ini disebabkan oleh berkurangnya ikatan rangkap terkonjugasi pada DPPH karena elektron pada radikal DPPH berpasangan dengan atom hidrogen dari antioksidan sehingga menjadi DPPH-H yang merupakan radikal stabil. Persentase pengikatan radikal DPPH kemudian digunakan pada perhitungan nilai $\mathrm{IC}_{50}$ untuk mengetahui seberapa besar konsentrasi ekstrak yang dapat memberikan peredaman DPPH sebesar 50\%. Nilai IC $_{50}$ dihitung berdasarkan persamaan regresi linear yang diperoleh dengan cara memplot log konsentrasi larutan uji dengan nilai probit persentase pengikatan radikal DPPH. Semakin kecil nilai $\mathrm{IC}_{50}$ menunjukkan semakin besar kemampuan antioksidannya.

Gambar 2 menunjukkan bahwa nilai IC $_{50}$ dari ekstrak kombinasi kayu secang dan bunga rosella secara berurutan dari aktivitas antioksidan terbesar hingga terkecil yaitu perbandingan kombinasi ekstrak 1:0 memiliki IC $\mathrm{IC}_{50}$ sebesar $11,456 \mu \mathrm{g} / \mathrm{ml}, 2: 1$ sebesar $12,335 \mu \mathrm{g} / \mathrm{ml}, 1: 1$ sebesar 16,785 $\mu \mathrm{g} / \mathrm{ml}, 1: 2$ sebesar 19,929 $\mu \mathrm{g} / \mathrm{ml}$. Kombinasi ekstrak kayu secang dan bunga rosella 1:0, 2:1, 1:1, dan 1:2 tergolong memiliki aktivitas antioksidan yang sangat kuat ( $\left.\mathrm{IC}_{50}<50 \mu \mathrm{g} / \mathrm{ml}\right)$.(20) Sedangkan, ekstrak bunga rosella 0:1 memiliki $\mathrm{IC}_{50}$ sebesar $680,371 \mu \mathrm{g} / \mathrm{ml}$ dan menunjukkan aktivitas antioksidan yang lemah $\left(\mathrm{IC}_{50}>150 \mu \mathrm{g} / \mathrm{ml}\right)(20)$. Histogram menunjukkan bahwa kenaikan konsentrasi ekstrak kayu secang pada kombinasi ekstrak mempengaruhi nilai IC $_{50}$. Semakin besar konsentrasi kayu secang, semakin besar aktivitas antioksidan. Sebaliknya, semakin besar konsentrasi 
bunga rosella pada kombinasi ekstrak, semakin kecil aktivitas antioksidan yang dihasilkan. Hal ini menunjukkan bahwa kayu secang memiliki aktivitas antioksidan yang lebih besar dibandingkan bunga rosella. Pengujian aktivitas antioksidan dengan kontrol positif larutan vitamin C diperoleh nilai $\mathrm{IC}_{50}$ sebesar $4,774 \mu \mathrm{g} / \mathrm{ml}$.

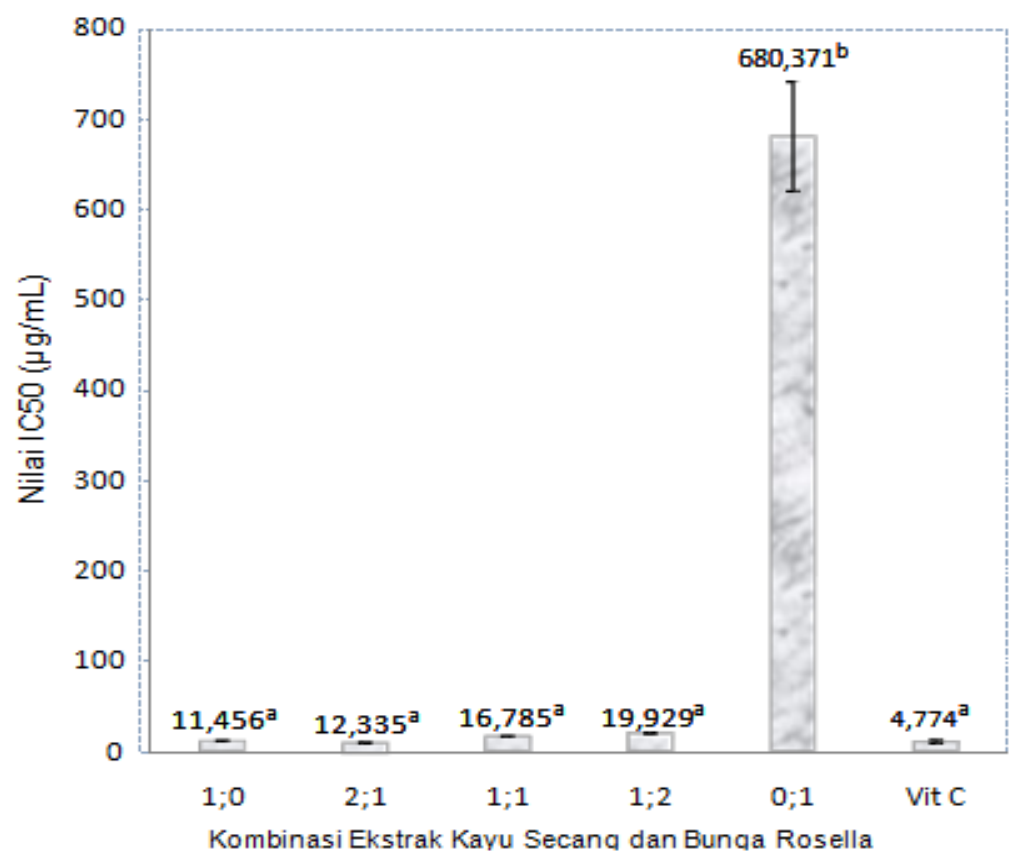

Gambar 2. Histogram Nilai Rata-rata IC50 \pm SD Kombinasi Ekstrak Etanol Kayu Secang (Caesalpinia sappan) dan Bunga Rosella (Hibiscus sabdariffa). Nilai yang diikuti huruf yang berbeda menunjukkan perbedaan sangat nyata $(\alpha<0,01)$

Hasil analisis statistik ANOVA satu arah menunjukkan bahwa perlakuan dengan kombinasi ekstrak kayu secang dan bunga rosella menunjukkan pengaruh sangat nyata $(\alpha<$ $0,01)$ terhadap aktivitas pengikatan radikal bebas DPPH. Hasil uji lanjutan dengan Beda Nyata Jarak Duncan (BNJD) menunjukkan bahwa IC $_{50}$ kombinasi ekstrak kayu secang dan bunga rosella dengan perbandingan 1:0, 2:1, 1:1, dan 1:2 berada pada subset yang sama dengan kontrol positif. Hal ini menunjukkan kombinasi ekstrak dengan perbandingan 1:0, $2: 1,1: 1$, dan $1: 2$ memiliki efek aktivitas antioksidan yang tidak berbeda nyata $(\alpha>0,05)$ dengan Vitamin C. Sedangkan, ekstrak tunggal bunga rosella berada pada subset yang berbeda dengan kontrol positif dan kombinasi lain, hal ini menunjukkan bahwa ekstrak bunga rosella memiliki aktivitas antioksidan yang lemah dan berbeda sangat nyata dengan kombinasi ekstrak 1:0, 2:1, 1:1, dan 1:2 yakni 680,371 $\mu \mathrm{g} / \mathrm{ml}$.

Aktivitas antioksidan kayu secang dan bunga rosella telah dilaporkan sebelumnya, yaitu ekstrak etanol kayu secang memiliki $\mathrm{IC}_{50} 13,406 \mu \mathrm{g} / \mathrm{ml}$, sedangkan $\mathrm{IC}_{50}$ bunga rosella adalah $465,88 \mu \mathrm{g} / \mathrm{ml}$ terhadap radikal bebas DPPH $(9,11)$. Kombinasi ekstrak yang memberikan aktivitas antioksidan yang tinggi ditunjukkan pada kombinasi ekstrak kayu secang (Caesalpinia sappan) dan bunga rosella (Hibiscus sabdariffa) dengan perbandingan 2:1 setelah ekstrak tunggal karena memiliki subset yang sama dengan kontrol positif Vitamin C. Namun, pemanfaatan ekstrak tunggal kayu secang perbandingan 1:0 lebih ekonomis dibandingkan dengan kombinasi ekstrak kayu secang dan ekstrak bunga rosella. Hal ini disebabkan tingginya harga bunga rosella dibandingkan kayu secang. Perhitungan Indeks Kombinasi (CI) ekstrak kayu secang dengan ekstrak bunga rosella pada 
perbandingan 2:1, 1:1, dan 1:2 menunjukkan efek yang sinergis $(\mathrm{CI}<1)$ yang dapat dilihat pada Gambar 3 (21).
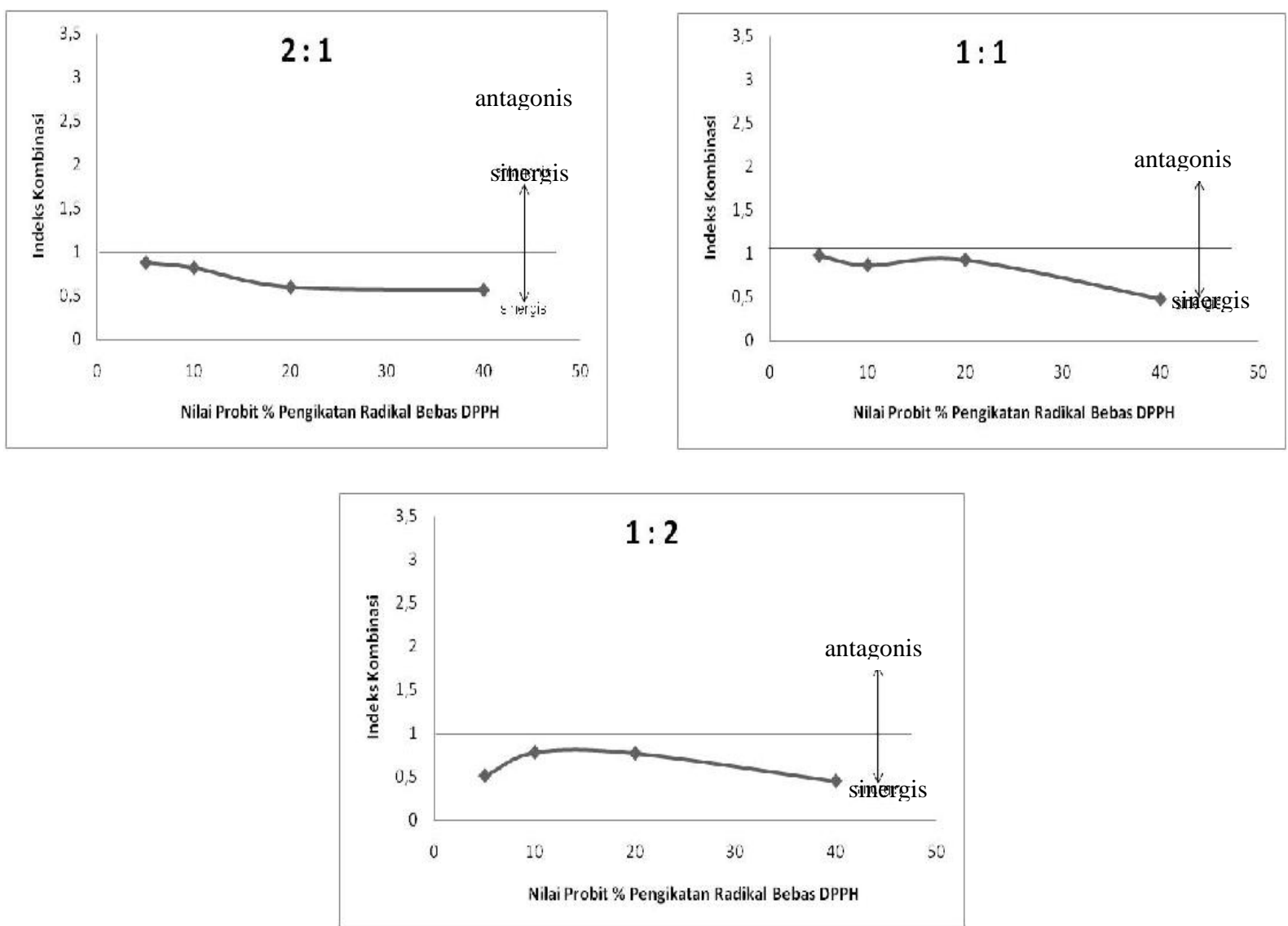

Gambar 3. Indeks kombinasi interaksi antara kombinasi ekstrak kayu secang dan bunga rosella perbandingan $2: 1 ; 1: 1$; dan $1: 2$

\section{KESIMPULAN}

Berdasarkan hasil penelitian di atas maka dapat disimpulkan bahwa:

1. Kombinasi ekstrak kayu secang-bunga rosella 2:1, 1:1, dan 1:2 memiliki aktivitas antioksidan yang sangat kuat dengan nilai $\mathrm{IC}_{50}$ berturut-turut sebesar 12,345; 16,79; dan $19,93 \mu \mathrm{g} / \mathrm{ml}(\mathrm{IC} 50<50 \mu \mathrm{g} / \mathrm{ml})$.

2. Perhitungan Indeks Kombinasi (CI) ekstrak kayu secang dengan ekstrak bunga rosella pada perbandingan $2: 1,1: 1$, dan 1:2 menunjukkan efek yang sinergis $(\mathrm{CI}<$ 1)

\section{DAFTAR PUSTAKA}

1. Singh RP, Sharad S, Kapur S. 2004. Free Radicals and Oxidative Stress in Neurodegenerative Diseases: Relevance of Dietary Antioxidants. Journal, Indian Academy of Clinical Medical. 5(3):218-25.

2. Bobrowski K. 2005. Free Radicals in Chemistry, Biology and Medicine : Contribution of Radiation Chemistry. Nukleonik. 50(3):S67-S76.

3. Scheibmeir HD, Christensen K, Whitaker SH, Jegaethesan J, Clancy R, Pierce JD. 2005. A Review of Free Radicals and Antioxidants for Critical Care Nurses. Intensive and Critical Care Nursing. 21:24-8.

4. Aqil F, Ahmad I, Mehmood Z. 2006. Antioxidant and Free Radical Scavenging 
Properties of Twelve Traditionally Used Indian Medicinal Plants. Turkish Journal of Biology. 30:177-83.

5. Badami S, Moorkoth S, Suresh B. 2004. Caesalpinia sappan a Medicinal and Dye Yielding Plant. Natural Product Radiance. 3(2):75-82.

6. Sundari D, Widowati L, Winarno MW. 1998. Informasi Khasiat, Keamanan dan Fitokimia Tanaman Secang (Caesalpinia sappan l.) Warta Tumbuhan Obat Indonesia. The Journal on Indonesian Medicinal Plants. 4(3):1-2.

7. Safitri R. 2002. Karakterisasi Sifat Antioksidan In Vitro Beberapa Senyawa yang Terkandung dalam Tumbuhan Secang (Caesalpinia sappan L.). Bandung : Disertasi Program Pasca Sarjana Universitas Padjadjaran.

8. Batubara I, Mitsugana T, Ohashi H. 2010. Brazilin from Caesalpinia sappan Wood as an Antiacne Agent. Journal of Wood Science. 56:77-81.

9. Penpun W, Thawatchai P, Sindhchai K. 2005. The Antioxidant Activity of Caesalpinia sappan L. Heartwood in Various Ages. Naresuan University Journal. 13(2):43-52.

10. Maryani H, Kristiana. 2008. Khasiat dan Manfaat Rosella. Jakarta : Agromedia Pustaka. 2-4, 6-7, 25-27.

11. Liuqing Y, Ying G, Ting Z, Jiangji Z, Fang L, Bingtao Z, Xiangyang W. 2012. Antioxidant Capacity of Extract from Calyx Fruits of Roselle (Hibiscus sabdariffa L.). African Journal of Biotechnology. 11(17) 4063-4068.

12. Unlu GV, Candan F, Sokmen A, Dafefera D, Polissiou M, Sokmen M, Donmez E, Tepe B. 2003. Antimicrobial and Antioxidant Activity of the Essential Oil and Methanol Extracts of Thymus pectinatus Fisch. et Mey. Var. pectinatus (Lamiaceae). Journal of Agricultural and Food Chemistry. 51:63-70.

13. Ryan M, Juanda, Syarifah R, Rita R. 2012. Efektivitas Penggunaan Jenis Pelarut dan Asam dalam Proses Ekstraksi Pigmen Antosianin Kelopak Bunga Rosella (Hibiscus sabdariffa L.). Jurnal Teknologi dan Industri Pertanian Indonesia. 4:3.

14. Jackman RL, Smith. 1996. Anthocyanins and Betalanins. Di dalam Natural Food Colorants. Hendry, G.A..F. dan J.D. Houghton (ed.). London : Blackie Academic \& Proffesional.

15. Ketaren S. 1986. Minyak dan Lemak Pangan. Jakarta : UI Press.

16. Bronnum H, Flink. 1985. Anthocyanin Colorants from Elderberry (Sambucus nigra L.). Journal of Food Technology. 20:714-723.

17. Sukhapat N, Ungphaiboon S, Itharat A, Puripattanavong, Pinsuwan S. 2004. Influence of $\mathrm{pH}$ on antioxidant activity of Roselle (Hibiscus sabdariffa L.) extract in aqueous solution. Thailand: The 10th World Congress on Clinical Nutrition: Nutrition in the Next Decade: Nutraceutical/Functional Food: Product Performance in Health, Disease and Safety. Abstract book. Organized by PSU, INC and BIOTEC.

18. Regina TP, Siti M, Antuni W. 2012. Karakter Ekstrak Zat Warna Kayu Secang (Caesalpinia sappan) Sebagai Indikator Titrasi Asam Basa. Yogyakarta: Prosiding Seminar Nasional Penelitian Universitas Negeri Yogyakarta.

19. Wen JL, Xian LC, Jing L, Rui CL, Gang LW, Shu SD, Zhi LL. 2012. Phenolic Compounds and Antioxidant Activities of Liriope muscari. China : Molecules. 17:1797-1808.

20. Ariyanto R. 2006. Uji aktivitas Antioksidan, Penentuan Kandungan Fenolik dan Flavonoid Total Fraksi Kloroform dan Fraksi Air Ekstrak Metanolik Pegagan (Cantella asiatica L. Urban). Fakultas Farmasi Universitas Gadjah Mada.

21. Chou JH. 1975. A General Procedure For Determination of Median-Effect Doses by A Double Logarithmic Transformation of Dose-Response Relationships. Federation Proceedings. 34: 228. 